\title{
UPAYA MENINGKATKAN KOMPETENSI GURU DALAM MENYUSUN RENCANA PELAKSANAAN PEMBELAJARAN (RPP) BERKARAKTER MELALUI SUPERVISI AKADEMIK DI SMK N 3 PATI
}

\author{
EFFORTS TO IMPROVE TEACHER COMPETENCY IN COMPILING \\ LESSON PLANS ( RPP ) CHARACTER \\ THROUGH ACADEMIC SUPERVISION IN SMK N 3 PATI
}

\author{
Sunoto \\ SMK Negeri 3 Pati \\ Email: afifsunoto@gmail.com
}

Naskah Masuk : 24 Maret 2016

Naskah Revisi : 20 April 2016

Naskah Diterima : 11 Mei 2016

\begin{abstract}
The background of this research is lower competency of teacher in SMK Negeri 3 Pati in preparing lesson plans character. Academic supervisions in SMK Negeri 3 Pati are conducted in order to improve the competency of teacher in preparing lesson plans character. The research subjects are the Islamic education teacher of grade X, the social science teacher of grade XII, the civic education teacher of grade X, the Indonesian language teacher of grade XI and the English language teacher of grade XI. This research method is descriptive with quantitative and qualitative approaches. The data are collected through documentation, observation, interviews and assignments. The research is designed through two cycles with procedure: (1) planning; (2) the action executions; (3) observation; and (4) reflection. The result shows that teacher's competency increases indicated by: 1) the average score for the first cycle is 71 rated "good"; and 2) the average score for the second cycle is 90 rated "very good". The conclusion of this study is that the implementation of the academic supervision can improve the competency of teacher in preparing the lesson plans character in SMK Negeri 3 Pati.
\end{abstract}

Keywords: competency of teacher, lesson plans character, academic supervision

\begin{abstract}
ABSTRAK
Penelitian ini dilatarbelakangi permasalahan rendahnya kompetensi guru dalam menyusun RPP berkarakter. Untuk mengatasi permasalahan ini, dilakukan supervisi akademik yang bertujuan untuk meningkatkan kompetensi guru dalam menyusun RPP berkarakter. Subjek penelitian adalah guru mata pelajaran Pendidikan agama Islam kelas X, Ilmu Pengetahuan Sosial kelas XII, Pendidikan Kewarganegaraan kelas X, Bahasa Indonesia Kelas XI dan Bahasa Inggris kelas XI. Metode penelitian ini adalah deskriptif dengan pendekatan kuantitatif dan kualitatif. Teknik pengumpulan data melalui dokumentasi, observasi, wawancara dan penugasan. Desain penelitian dirancang melalui dua siklus dengan prosedur: 1) Perencanaan; 2) Pelaksanaan tindakan; 3) Pengamatan; dan 4) Refleksi. Hasil penelitian menunjukkan peningkatan kompetensi, untuk siklus I sebesar 71 poin dinilai "baik" dan siklus II sebesar 90 poin dinilai "sangat baik". Dengan demikian dapat disimpulkan bahwa pelaksanaan supervisi akademik dapat meningkatkan kompetensi guru dalam menyusun RPP berkarakter di SMK Negeri 3 Pati.
\end{abstract}

Kata kunci: kompetensi guru, RPP berkarakter, supervisi akademik 


\section{PENDAHULUAN}

Peraturan Pemerintah Nomor 19 Tahun 2005 tentang Standar Nasional Pendidikan mengamanatkan bahwa setiap pendidik harus memiliki kualifikasi akademik dan kompetensi sebagai agen pembelajaran, sehat jasmani dan rohani serta memiliki kemampuan untuk mewujudkan tujuan pendidikan nasional.

Setiap guru harus mampu menyusun Rencana Pelaksanaan Pembelajaran (RPP) sesuai dengan kaidah-kaidah yang telah ditentukan yang idealnya berdasarkan KTSP. Namun masalah penting yang sering dihadapi guru dalam kegiatan pembelajaran adalah menyiapkan RPP yang tepat dalam rangka membantu siswa mencapai kompetensi. Hal ini disebabkan oleh kenyataan bahwa dalam kurikulum atau silabus, RPP hanya dituliskan secara garis besar dalam bentuk "materi acuan untuk mengajar". Hal ini menjadi tugas guru untuk menjabarkan materi acuan untuk mengajar tersebut sehingga menjadi bahan ajar yang lengkap. Selain itu, bagaimana cara memanfaatkan bahan ajar juga merupakan masalah. Pemanfaatan yang dimaksud dalam hal ini adalah bagaimana cara mengajarkannya ditinjau dari pihak guru, dan cara menyampaikannya kepada siswa. Selain itu, kesulitan yang dialami guru dalam menyusun perencanaan pembelajaran yaitu: merumuskan tujuan pembelajaran yang lengkap, menyeimbangkan antara waktu yang disediakan oleh kurikulum dengan materi dan sebagainya.

Observasi awal pada hari Rabu tanggal 16 Oktober 2013 di SMK Negeri 3 Pati, menunjukkan hasil bahwa :
1. Lebih dari $90 \%$ para guru tidak membuat RPP sendiri, karena RPP yang digunakan adalah RPP hasil copy paste dari produk karya orang lain atau men-download dari internet;

2. Belum semua guru memahami pentingnya Pendidikan Budaya Karakter Bangsa (PBKB) dalam kegiatan pembelajaran, sehingga guru belum mampu mengimplementasikan RPP dengan pengintegrasian pendidikan berkarakter bangsa dalam kegiatan pembelajaran;

3. Dalam penyusunan RPP berkarakter bangsa, kebanyakan guru kurang menjelaskan apa yang dilakukan siswa selama berlangsungnya pembelajaran dalam rencana kegiatan pembelajarannya, tidak menjelaskan sumber belajar dengan rinci, tidak menjelaskan: 1) Bentuk instrumen evaluasi;

Format/lembaran evaluasi atau butir soal (pre test dan post test); 3) Pedoman penilaian; dan 4) Kunci jawaban, dalam evaluasi proses dan hasil belajar siswa, tidak merencanakan tindak lanjut setelah selesai pembelajaran (pembelajaran remedial, program pengayaan, layanan konseling atau tugas individu/kelompok) dalam kaitan antara KKM mata pelajaran dengan nilai yang dicapai siswa;

4. Para guru pada umumnya menghadapi permasalahan dalam hal: 1) Penetapan indikator yang terukur; 2) Membuka pelajaran dengan kegiatan yang menarik perhatian dan mampu memotivasi belajar siswa; 3) Menutup pelajaran dengan baik; dan 4) Mendesain pembelajaran aktif, kreatif, inovatif, menyenangkan dan berbobot; 
5. Dalam penyusunan RPP, guru belum seluruhnya mencantumkan rubrik untuk penilaian Pendidikan Budaya Karakter Bangsa (PBKB);

6. Sebagian besar guru membuat RPP bermuatan PBKB hanya untuk memenuhi tuntutan administrasi.

Penyebab rendahnya kompetensi guru dalam menyusun Rencana Pelaksanaan Pembelajaran (RPP) berkarakter bangsa dikarenakan: 1) Kurangnya pemahaman guru terhadap penyusunan RPP berkarakter; 2) Kurangnya sosialisasi mengenai penyusunan RPP berkarakter, sehingga guru mengalami kesulitan dan kebingungan dalam proses pembuatannya; 3) Kurangnya pembinaan, pembimbingan secara berkelanjutan baik melalui diklat, pendampingan maupun supervisi akademik.

Kekurangpahaman guru dan penyelenggara pendidikan terhadap kurikulum dan pengembangannya ke dalam RPP berkarakter bangsa bisa berakibat fatal terhadap hasil belajar peserta didik. Kondisi tersebut, tentu saja tidak dapat dibiarkan terus menerus, tetapi harus ada solusi atau tindakan nyata dari kalangan para pengawas dan kepala sekolah untuk meningkatkan kompetensi guru dalam menyusun RPP berkarakter bangsa sesuai dengan ketentuan kurikulum yang berlaku.

Berdasarkan latar belakang tersebut, maka tujuan penelitian ini adalah untuk meningkatkan kompetensi guru dalam menyusun RPP berkarakter bangsa melalui pelaksanaan supervisi akademik di SMK Negeri 3 Pati.

\section{TINJAUAN PUSTAKA}

\section{Kompetensi Guru}

Pengertian kompetensi guru adalah seperangkat penguasaan kemampuan yang harus ada dalam diri guru agar dapat mewujudkan kinerjanya secara tepat dan efektif (Kunandar, 2007). Kompetensi guru yang dimaksud adalah yang termaktub dalam Undang-undang Republik Indonesia Nomor 14 Tahun 2005 tentang Guru dan Dosen Bab IV Pasal 8 yang menyatakan bahwa guru wajib memiliki kualifikasi akademik, kompetensi, sertifikat pendidik, sehat jasmani dan rohani, serta memiliki kemampuan untuk mewujudkan tujuan pendidikan nasional. Selanjutnya Pasal 10 Ayat 1 menyebutkan empat kompetensi yang harus dimiliki oleh guru meliputi: kompetensi pedagogik, kompetensi kepribadian, kompetensi sosial, dan kompetensi profesional.

\section{Pendidikan Karakter}

Menurut Grand Design Pendidikan Karakter Kementerian Pendidikan Nasional (2010), pendidikan karakter merupakan suatu proses pembudayaan dan pemberdayaan peserta didik agar memiliki nilai-nilai luhur dan perilaku berkarakter, yang meliputi ranah olah pikir, olah hati, olah raga (kinesthetik), dan olah rasa.

Pendidikan karakter menanamkan kebiasaan (habituation) tentang hal mana yang baik sehingga peserta didik menjadi paham (kognitif) tentang mana yang benar dan yang salah, mampu merasakan (afektif) nilai yang baik dan biasa melakukannya (psikomotor). Dengan kata lain, pendidikan karakter yang baik bukan hanya melibatkan aspek pengetahuan yang baik (moral knowing), akan tetapi juga merasakan yang baik (moral feeling) dan perilaku yang baik (moral action). 


\section{Rencana Pelaksanaan Pembelajaran}

Berdasarkan

Peraturan

Pemerintah Nomor 19 Tahun 2005 tentang Standar Nasional Pendidikan (SNP) Pasal 20 yang menyatakan bahwa perencanaan proses pembelajaran meliputi silabus dan rencana pelaksanaan pembelajaran yang memuat sekurang-kurangnya tujuan pembelajaran, materi ajar, metode pengajaran, sumber belajar, dan penilaian hasil belajar. Di dalam Permendiknas Nomor 41 Tahun 2007 tentang Standar Proses dijelaskan bahwa RPP dijabarkan dari silabus untuk mengarahkan kegiatan belajar peserta didik dalam upaya mencapai KD.

Adapun prinsip pengembangan RPP yang harus diperhatikan adalah sebagai berikut: 1) Memperhatikan perbedaan individu peserta didik; 2) Mendorong partisipasi aktif peserta didik; 3) Mengembangkan budaya membaca dan menulis; 4) Memberikan umpan balik dan tindak lanjut; 5) Keterkaitan dan keterpaduan; dan 6) Menerapkan teknologi informasi dan komunikasi.

\section{Supervisi Akademik}

Pengertian supervisi adalah serangkaian usaha pemberian bantuan kepada guru dalam bentuk layanan profesional yang diberikan oleh supervisor (pengawas sekolah, kepala sekolah, dan pembina lainnya) guna meningkatkan mutu proses dan hasil belajar mengajar.

Tujuan supervisi akademik adalah: 1) Membantu guru mengembangkan kompetensinya; 2) Mengembangkan kurikulum; dan 3) Mengembangkan kelompok kerja guru, dan membimbing Penelitian Tindakan Kelas (PTK) (Glickman et al, 2007; Sergiovanni, 1987). Prinsip-prinsip supervisi akademik adalah praktis, sistematis, objektif, realistis, antisipatif, konstruktif, kooperatif, kekeluargaan, demokratis, aktif, humanis, berkesinambungan, terpadu dan komprehensif (Dodd, 1972).

\section{METODE PENELITIAN}

Penelitian ini dilaksanakan di SMK Negeri 3 Pati, mulai tanggal 3 Oktober 2013 sampai dengan 25 Januari 2014 dengan jumlah guru yang diteliti sebanyak 5 orang. Sumber data berasal dari data kuantitatif dan kualitatif, dengan teknik pengumpulan melalui metode dokumentasi, observasi, wawancara, dan penugasan. Instrumen yang digunakan dalam penelitian ini adalah penilaian kompetensi guru dalam menyusun Rencana Pelaksanaan Pembelajaran (RPP) Berkarakter. Validasi data yang digunakan yaitu trianggulasi data, trianggulasi teori dan review informan. Teknik analisis data meliputi reduksi data, penyajian data, dan penarikan kesimpulan atau verifikasi. Indikator pencapaian hasil yang diharapkan $90 \%$ guru SMK Negeri 3 Pati mampu menyusun RPP berkarakter yang sesuai dengan karakteristik siswa dan kondisi sekolah. Penelitian ini dilaksanakan dengan menggunakan desain penelitian tindakan (action research) yang dirancang melalui dua siklus melalui prosedur: 1) Perencanaan (planning); 2) Pelaksanaan tindakan (action); 3) Pengamatan (observation); 4) Refleksi (reflection) dalam tiap-tiap siklus.

\section{HASIL PENELITIAN DAN PEMBAHASAN}

\section{Deskripsi Pra Siklus}

Rekapitulasi hasil penilaian kompetensi guru pada penyusunan RPP berkarakter bangsa sebelum diadakan tindakan (Pra Siklus) tercantum pada Tabel 1. 
Tabel 1.

Rekapitulasi Hasil Penilaian Kompetensi guru dalam Menyusun RPP yang diintegrasikan ke dalam (PBKB) Tahap Pra Siklus

\begin{tabular}{lccc}
\hline \multicolumn{1}{c}{ Kategori } & Rentang Nilai & f & Persentase (\%) \\
\hline Kurang Baik & $\leq 40$ & 4 & 80 \\
Cukup & $41-65$ & 1 & 20 \\
Baik & $66-80$ & 0 & 0 \\
Sangat Baik & $81-100$ & 0 & 0 \\
Jumlah & & 5 & 100 \\
\hline
\end{tabular}

Sumber: Pengolahan Data (2014)

Dari Tabel 1 di atas terlihat bahwa kualitas hasil penyusunan RPP berkarakter bangsa sebelum diadakan supervisi akademik dapat dikategorikan "kurang baik" terbukti adanya nilai rata-rata sebesar 32 poin $(32 \%)$. Hal ini terlihat ada 4 orang atau $80 \%$ guru kurang berkualitas dalam penyusunan RPP berkarakter bangsa, belum mampu menyusun RPP berkarakter bangsa secara lengkap dan sistematis. Selanjutnya ada 1 orang atau $20 \%$ guru memiliki kemampuan cukup dalam menyusun RPP berkarakter bangsa secara lengkap dan sistematis mengacu pada Permendiknas Nomor 41 Tahun 2007 tentang Standar Proses. Hal ini terjadi karena kurangnya kompetensi guru dalam penyusunan RPP berkarakter bangsa, disebabkan oleh beberapa faktor penghambat diantaranya: 1) Guru belum memiliki panduan penyusunan RPP yaitu Permendiknas Nomor 41 Tahun 2007 tentang Standar Proses; 2) Sebagian besar guru belum mendapatkan pelatihan pengembangan KTSP, sehingga RPP yang dibuat guru komponennya belum lengkap khususnya pada komponen langkahlangkah pembelajaran dan penilaian yang belum ada pengintegrasian pendidikan karakter bangsa; dan 3) Pelaksanaan supervisi akademik di SMK Negeri 3 Pati belum terjadwal secara teratur. Berpijak dari hasil observasi tersebut, maka peneliti selaku Kepala SMK Negeri 3 Pati berusaha mengatasi permasalahan tersebut dengan melaksanakan supervisi akademik.

\section{Deskripsi Siklus I}

Tahapan tindakan Siklus I dengan langkah-langkah: Pertama, Perencanaan (Planning): a) Membuat lembar wawancara; b) Membuat format/instrumen penilaian RPP; dan c) Membuat format rekapitulasi hasil penyusunan RPP siklus I. Kedua, Pelaksanaan Tindakan (Acting) dilaksanakan 4 kali pertemuan dengan langkah-langkah: a) Pembinaan dalam penyusunan RPP sesuai standar proses; b) Penilaian terhadap kompetensi guru dalam menyusun RPP berkarakter bangsa; c) Membimbing guru dalam perencanaan pembelajaran: mulai dari menyusun rencana pengajaran, menyiapkan metode, membuat media belajar, menyiapkan sumber belajar, dan menyiapkan alat evaluasi; d) Pendampingan terhadap guru saat melaksanakan kegiatan pembelajaran baik di dalam kelas maupun di luar kelas, sesuai dengan tema dan materi yang akan diajarkan; dan e) 
Pendampingan guru saat mengevaluasi hasil belajar terhadap siswa.

Ketiga,

(Observation) meliputi:

Pengamatan

Pengembangan materi pengajaran yang dilakukan guru; b) Strategi pembelajaran yang dikembangkan guru; c) Metode pembelajaran yang dipilih dan ditampilkan guru dalam pembelajaran di kelas; d) Media pengajaran yang dipilih dan ditampilkan guru dalam pembelajaran di kelas; dan e) Sumber belajar yang dipilih dan dipergunakan guru dalam kegiatan pembelajaran.

Hasil penilaian kompetensi guru menyusun RPP berkarakter bangsa disajikan dalam Tabel 2.

Tabel 2.

Hasil Penilaian Kompetensi guru dalam Menyusun RPP yang diintegrasikan ke dalam (PBKB) Tahap Siklus I

\begin{tabular}{lccc}
\hline \multicolumn{1}{c}{ Kategori } & Rentang Nilai & f & Persentase (\%) \\
\hline Kurang Baik & $\leq 40$ & - & - \\
Cukup & $41-65$ & 2 & 40 \\
Baik & $66-80$ & 3 & 60 \\
Sangat Baik & $81-100$ & - & - \\
Jumlah & & 5 & 100 \\
\hline
\end{tabular}

Sumber: Pengolahan Data (2014)

Dari Tabel 2 di atas menunjukkan bahwa kualitas hasil penyusunan RPP berkarakter bangsa setelah diadakan supervisi akademik dapat dikategorikan "baik" terbukti adanya nilai rata-rata sebesar 71 poin. Hal ini terlihat ada 3 orang atau $60 \%$ guru, dinilai "baik" dalam penyusunan RPP yang sudah lengkap dan sistematis. Hal ini berarti guru mampu menyusun RPP sesuai dengan Permendiknas Nomor 41 Tahun 2007 dan dapat diterapkan ke dalam proses pembelajaran dengan dipadukan pada Pendidikan Budaya Karakter Bangsa (PBKB). Selanjutnya ada 2 orang atau $40 \%$ guru dinilai "cukup" dalam penyusunan RPP. Dalam hal ini guru sudah menyusun RPP berkarakter bangsa dengan lengkap namun kurang interaktif.

Berpijak pada hasil observasi Siklus I, ada $71 \%$ guru binaan peneliti memiliki kemampuan yang baik dalam menyusun RPP berkarakter bangsa secara lengkap dan sistematis. Namun masih ada guru yang menyusun RPP tidak dilengkapi dengan teknik dan bentuk instrumen, soal, pedoman penskoran, dan kunci jawaban. Oleh karena itu perlu diadakan penyempurnaan/perbaikan pada kegiatan supervisi akademik selanjutnya, dengan ketentuan: 1) Guru harus menyusun sendiri RPP dengan pengintegrasian pendidikan budaya karakter bangsa yang disesuaikan dengan kondisi sekolah dan karakteristik peserta didik; 2) Dalam penyusunan RPP berkarakter bangsa harus mengacu pada Standar Proses; dan 3) Tidak diperkenankan guru mengadopsi RPP buatan sekolah lain tanpa disesuaikan dengan kondisi sekolah dan peserta didik. Dari hasil penilaian Siklus I, peneliti memutuskan 
untuk melanjutkan penelitian tindakan perbaikan pada Siklus II.

\section{Deskripsi Siklus II}

Tahapan tindakan Siklus II (sama dengan sikuls I) dengan langkahlangkah: 1) Perencanaan (Planning); 2)
Pelaksanaan (Acting); dan 3) Pengamatan (Observation).

Hasil penilaian kompetensi guru menyusun RPP berkarakter bangsa setelah diadakan supervisi akademik pada tindakan siklus II tersaji pada Tabel 3.

\section{Tabel 3.}

Hasil Penilaian Kompetensi guru dalam Menyusun RPP yang diintegrasikan ke dalam (PBKB) Tahap Siklus II

\begin{tabular}{lccc}
\hline \multicolumn{1}{c}{ Kategori } & Rentang Nilai & f & Persentase (\%) \\
\hline Kurang Baik & $\leq 40$ & - & - \\
Cukup & $41-65$ & - & - \\
Baik & $66-80$ & 1 & $20 \%$ \\
Sangat Baik & $81-100$ & 4 & $80 \%$ \\
Jumlah & & 5 & $100 \%$ \\
\hline
\end{tabular}

Sumber: Pengolahan Data (2014)

Dari Tabel 3 di atas terlihat bahwa kualitas hasil penyusunan RPP berkarakter bangsa setelah diadakan supervisi akademik dapat dikategorikan "sangat baik" terbukti adanya nilai rata-rata sebesar 90 poin. Hal ini terlihat ada 4 orang atau $80 \%$ guru sudah dinilai "sangat baik" dalam penyusunan RPP yang sudah diintegrasikan ke dalam pendidikan budaya karakter bangsa. Hal ini berarti guru mampu menyusun RPP secara lengkap dan sistematis sesuai dengan Permendiknas Nomor 41 Tahun 2007 dan dapat diterapkan ke dalam proses pembelajaran dengan dipadukan pada Pendidikan Budaya Karakter Bangsa (PBKB). Selanjutnya ada 1 orang atau $20 \%$ guru dinilai "baik" dalam penyusunan RPP. Dalam hal ini guru sudah menyusun RPP berkarakter bangsa dengan lengkap namun kurang interaktif. Kondisi ini membuktikan bahwa guru sudah mampu menyusun RPP yang diintegrasikan pada Pendidikan Budaya Karakter Bangsa
(PBKB). Hasil penelitian tersebut (siklus I dan siklus II) menunjukkan adanya trend peningkatan kompetensi guru dalam menyusun RPP berkarakter bangsa melalui supervisi akademik di SMK Negeri 3 Pati pada tahun pelajaran 2013-2014.

Pada Siklus II dapat disimpulkan bahwa setelah diadakan supervisi akademik, seluruh guru yang diteliti (5 orang guru) memiliki kemampuan yang sangat baik dalam menyusun RPP secara lengkap dan sistematis dan hasil RPP yang disusun dapat diterapkan ke dalam kegiatan pembelajaran di dalam kelas maupun di luar kelas dengan dipadukan pada Pendidikan Budaya Karakter Bangsa (PBKB). Oleh karena itu peneliti memutuskan untuk tidak melanjutkan ke siklus berikutnya.

\section{KESIMPULAN DAN SARAN}

\section{Kesimpulan}

Berdasarkan keseluruhan siklus yang telah dilakukan, disimpulkan bahwa : pelaksanaan supervisi 
akademik dapat meningkatkan kompetensi guru dalam menyusun RPP berkarakter di SMK Negeri 3 Pati. Peningkatan kompetensi guru dalam menyusun RPP berkarakter bangsa, yaitu : 1) Siklus I, kompetensi guru dalam menyusun RPP berkarakter dinilai "baik" dengan nilai rata-rata yang dicapai sebesar 71 poin, pada siklus I ada peningkatan sebesar 39 poin, dan 2) Siklus II, kompetensi guru dalam menyusun RPP berkarakter bangsa dinilai "sangat baik" dengan nilai rata-rata yang dicapai sebesar 90, pada siklus II ada peningkatan sebesar 19 poin.

\section{Saran}

1. Bagi para Pengawas Sekolah dan Kepala Sekolah, harus melaksanakan supervisi akademik secara terencana, berkala dan berkesinambungan khususnya terhadap perencanaan, dan pelaksanaan proses pembelajaran dan pembuatan perangkat pembelajaran yang berbasis pendidikan karakter bangsa.

2. Bagi Guru: a) Dengan kemampuan yang telah dimiliki, maka setiap guru seyogyanya menyusun koleksi RPP berkarakter bangsa dengan menerapkan model pembelajaraan inovatif untuk menciptakan iklim pembelajaran aktif, kreatif, efektif dan menyenangkan sesuai dengan mata pelajaran yang diampu; b) Hendaknya guru dalam merencanakan pembelajaran berpedoman pada Rencana Pelaksanaan Pembelajaran dengan mengimplementasikan strategi dan model pembelajaran yang sesuai karakteristik siswa sehingga tercipta proses pembelajaran yang kondusif, efektif dan efisien.

\section{DAFTAR PUSTAKA}

Dodd, W. A. 1972. Primary School Inspection in New Countries.
London: Oxford University Press.

Glickman, C. D., Gordon, S. P., and Ross-Gordon, J. M. 2007. Supervision and Instructional Leadership A Development Approach. Seventh Edition. Boston: Perason.

Kunandar. 2007. Guru Profesional: Implementasi Kurikulum Tingkat Satuan Pendidikan dan Sukses Dalam Sertifikasi Guru. Cetakan ke -1. Jakarta: Raja Grafindo Persada.

Peraturan Pemerintah Republik Indonesia Nomor 19 Tahun 2005 tentang Standar Nasional Pendidikan.

Peraturan Menteri Pendidikan Nasional Republik Indonesia Nomor 41 Tahun 2007 tentang Standar Proses untuk Satuan Pendidikan Dasar dan Menengah.

Kementerian Pendidikan Nasional. 2010. Pusat Kurikulum Badan Penelitian Pengembangan Kemendiknas. Bahan Pelatihan: Pengembangan Pendidikan Budaya Bangsa.

Sergiovanni, T. J. 1987. Supervision of Teaching. Alexandria: Association for Supervision and Curriculum Development.

Undang-Undang Republik Indonesia Nomor 14 Tahun 2005 tentang Guru dan Dosen.

\section{BIODATA PENULIS}

Drs. H. Sunoto, MM, Kepala SMK Negeri 3 Pati. Lahir di Pati pada tanggal 17 April 1965. Alumni S2 Manajemen Universitas Widya Gama Malang. 